\title{
Seasonality of reproduction and production in farm fishes, birds and mammals
}

\author{
P. Chemineau ${ }^{1 \dagger}$, B. Malpaux ${ }^{2}$, J. P. Brillard ${ }^{2}$ and A. Fostier ${ }^{3}$
}

\begin{abstract}
${ }^{1}$ INRA Département 'Physiologie Animale et Systèmes d'Elevage', INRA, 37380 Nouzilly, France; ${ }^{2}$ INRA UMR Physiologie de la Reproduction et des Comportements, INRA, CNRS, Haras Nationaux, Univ. F. Rabelais, 37380 Nouzilly, France; ${ }^{3}$ INRA Station Commune de Recherches en Ichtyophysiologie, Biodiversité et Environnement, INRA, Campus de Beaulieu, 35042 Rennes Cedex, France
\end{abstract}

(Received 3 September 2006; Accepted 15 January 2007)

\begin{abstract}
A very large majority of farm animals express seasonal variations in their production traits, thus inducing seasonal availability of fresh derived animal products (meat, milk, cheese and eggs). This pattern is in part the consequence of the farmer's objective to market his products in the most economically favourable period. It may also be imposed by the season-dependent access to feed resources, as in ruminants, or by the specific requirements derived from adaptation to environmental conditions such as water temperature in fish. But seasonal variations in animal products are also the consequence of constraints resulting from the occurrence of a more or less marked seasonal reproductive season in most farm animal species including fish, poultry and mammals. Like their wild counterparts, at mid and high latitudes, most farm animals normally give birth at the end of winter-early spring, the most favourable period for the progeny to survive and thus promote the next generation. As a consequence, most species show seasonal variations in their ovulation frequency (mammals and fish: presence or absence of ovulation; birds: variations or suppression of laying rates), spermatogenic activity (from moderate to complete absence of sperm production), gamete quality (variations in fertilisation rates and embryo survival), and also sexual behaviour. Among species of interest for animal production, fishes and birds are generally considered as more directly sensitive to external factors (mainly temperature in fish, photoperiod in birds). In all species, it is therefore advisable that artificial photoperiodic treatments consisting of extra-light during natural short days (in chickens, turkeys, guinea fowl, sheep and goats) or melatonin during long days (in goats, sheep) be extensively used to either adjust the breeding season to animal producer needs and/or to completely overcome seasonal variations of sperm production in artificial insemination centres (mammals) and breeder flock operations (poultry, fish farming). Pure light treatments (without melatonin), especially when applied in open barns, could be considered as non invasive ones which fully respect animal welfare.
\end{abstract}

Keywords: birds, fish, mammals, photoperiod, reproduction, seasonality

\section{Seasonal variations in marketed products of animal origin}

Seasonal availability of animal products for human consumption has been common long before domestication. In farm animals this pattern has led to the development of breeding stocks aimed at providing animal products all the year round. Despite the fact that domestication processes, which reduce the dependency of farm animals on natural conditions, generally reduce seasonality of reproduction compared with their wild counterparts, a majority of animal-derived products remain accessible only seasonally. This is a consequence of the cycles of reproduction and

\footnotetext{
${ }^{\dagger}$ E-mail: chemine@tours.inra.fr
}

production which are themselves seasonal as domestic stock have inherited the characteristics of the natural populations from which they originate (see below and Ortavant et al. (1985) also Bronson (1989)).

From an economic standpoint, mass distribution controls large portions of the market in animal products with a long-lasting evolution, such as with poultry, towards further-processed rather than fresh products. This has boosted the demand for more standardised products, a trend now shared by distributors and consumers who are increasingly becoming far distant, culturally, from agricultural constraints, and demand access to most types of animal products, in quantity and quality, throughout the year. As a consequence products like goat cheese, lamb meat, eggs and fish filets have become available year round. 
In recent years, European animal production systems have changed dramatically. This has lead to two alternative strategies which can be defined schematically as (a) intensive systems in which farm animals are expected to be less dependent on their environment and (b) extensive systems in which animals are subjected to the natural variations of their environment. These rapid changes have meant the control of seasonal production and reproduction in farm animals have become major research goals. Moreover, the increased knowledge on physiological and genomic control of these traits will facilitate inter-species comparisons regarding adaptative strategies. This will help in choosing the best breeding periods and will also provide useful information to adapt current and develop new control reproduction techniques (Malpaux et al., 2001; Malpaux, 2006).

Under temperate climates, a large majority of marketable animal products show quantitative and qualitative seasonal variations. These include the quantity of lambs and kids, the quality of dairy cattle milk and the collection of sheep and goat milk which greatly vary throughout the year. That induces high variations in the price paid to producers and/or in the ability of these different products to be processed by the food industry. For example in cow milk, fat and protein contents are low in spring and summer but high in autumn and winter (Figure 1). In France, goat milk production is highly seasonal, ranging from over 30 millions litres in May to about 10 millions in November (Figure 2). That induces wide variations in prices paid to the producer $(53 \%)$. Similarly, monthly mean production of lambs is low in October and high in April, causing significant changes to the market price of lamb meat (Figure 3). In extensive poultry systems of production, which constitute a minority of farmers in Europe and other developed countries, availability of meat and eggs is also seasonal with large variations between species. Thus in France, the 'natural' hatching period for free-range chickens extends from early March to mid October while in guinea fowl it is from late April to mid September. Similarly, fish farming products may also be marketed in a very seasonal way according to species and production systems.

The reasons of such variations will be discussed below. The milk industry has long been able to adapt technically to remedy these variations in order to provide a regular product to the consumer but this requires expensive technological processing. Thus in recent years the food industry has put pressure on milk producers to adapt their production systems to give a more constant final product (see section below: Using artificial photoperiodic treatments).

However, a significant number of the above cited variations in milk production (quantity and quality) are, for various reasons, due to pre-determined adjustments of the lactation period by milk producers. Such adjustments may have significant impact on milk quality especially in dairy cows for which producers schedule fertilisations in order to synchronise calvings and therefore milk production with the period of maximum food availability. In dairy cattle, in which ovulations occur all year round, it is the breeder's decision rather than occurrence of a rest season, which determines the dates of conceptions. In contrast, in a majority of seasonal breeding species, including sheep and goats, induced ovulations are generally required if farmers want to fertilise females for a specific season, out of the breeding season.

Thus, seasonality of animal product availability is the result of several intricate factors which link breeder's decisions to the underlying physiological mechanisms of the adaptation of farm animals to local environmental conditions. We will focus here on the basic mechanisms involved in the seasonal variations of reproductive activity which we consider as one of the main remaining constraints within some domestic animal

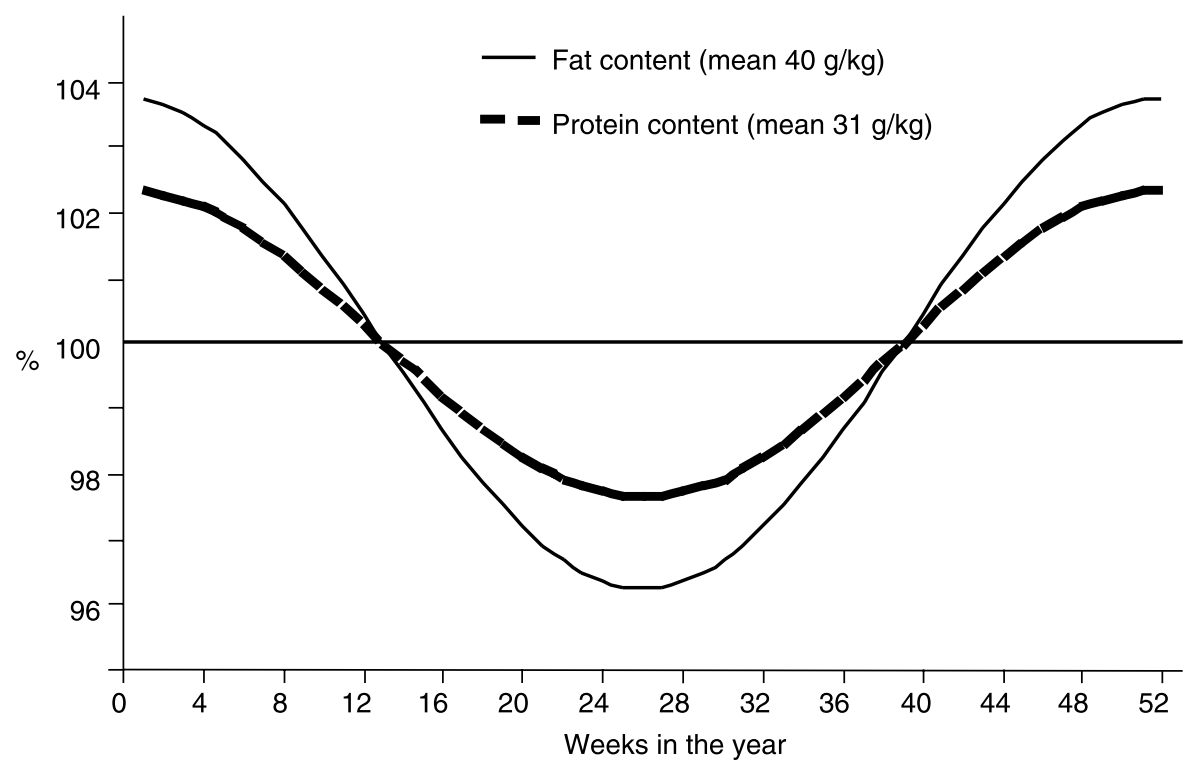

Figure 1 Seasonal variations (\% of the annual mean) in dairy cattle milk composition in France (adapted from Coulon et al. (1991)). 


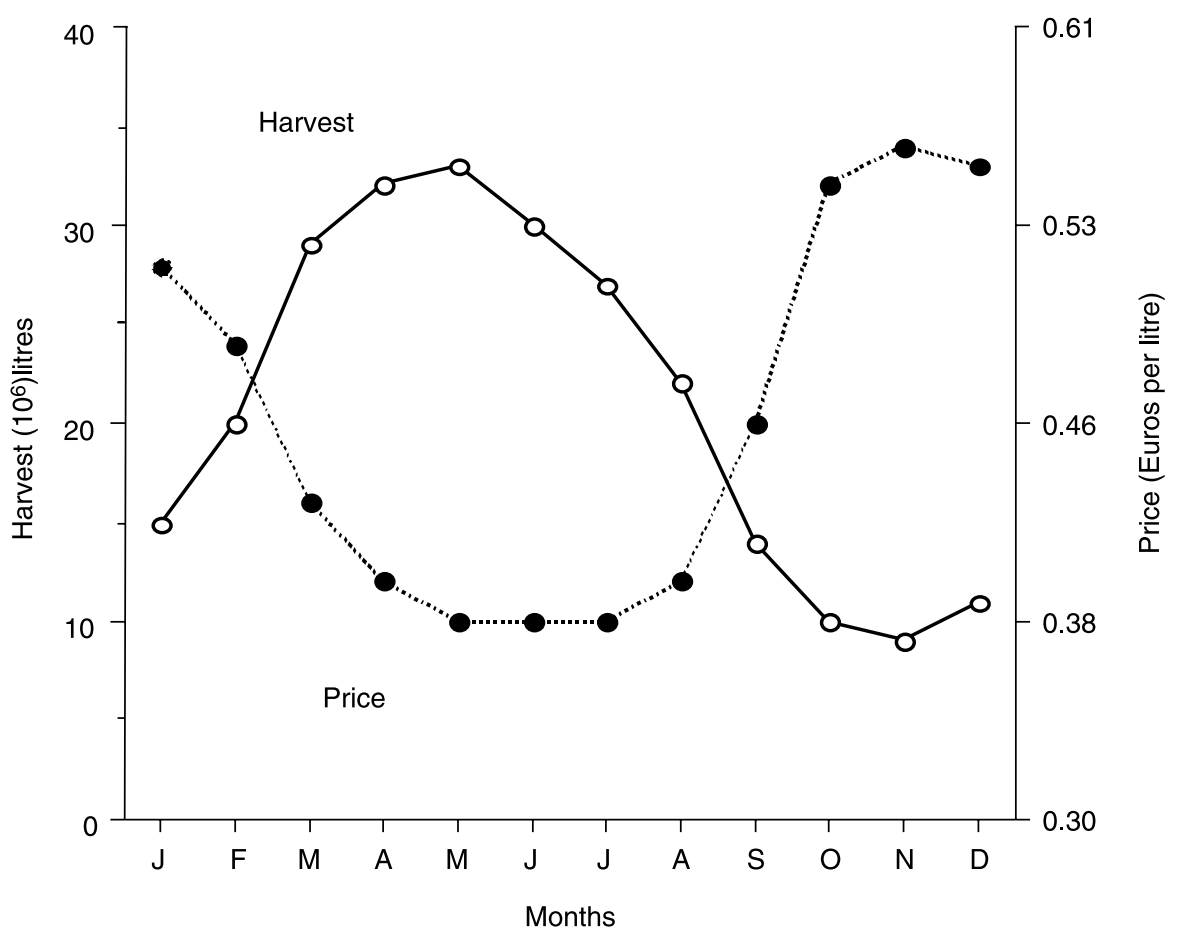

Figure 2 Seasonal variations in the harvest and farm price of goat milk in France (year 1992; adapted from Chemineau et al. (1996)).

populations. As our domestic animals are, with the exception of certain new fish species, the result of a very long process of domestication from wild populations, it is worth exploring whether the ancestors of domestic animals and their wildlife equivalents show natural seasonality of reproductive activity.

\section{Seasonality of reproductive activity is an old story first shown by wild species}

The occurrence of a specific lambing season in sheep of the Late Stone Age (end of 2nd millennium BC) was shown in South Africa by monitoring the ratio of several stable oxygen isotopes in tooth enamel (Balasse et al.,
2003). More recently, using the same technique in sheep teeth collected in the north of Scotland and in the extreme west of Brittany, Balasse et al. (2006) demonstrated the existence of a more intense expression of seasonality (lambing season) in sheep originating from Scotland compared with Brittany. Despite thousands of generations of human-controlled selection the results indicate that seasonality has not been bred out of the majority of 'modern' domestic species.

Authors having described the occurrence of a seasonal dependence of reproductive activity in wild mammalian species living in temperate zones are numerous with time of littering being taken as the main reference in most reports. In a majority of cases, the littering season occurs

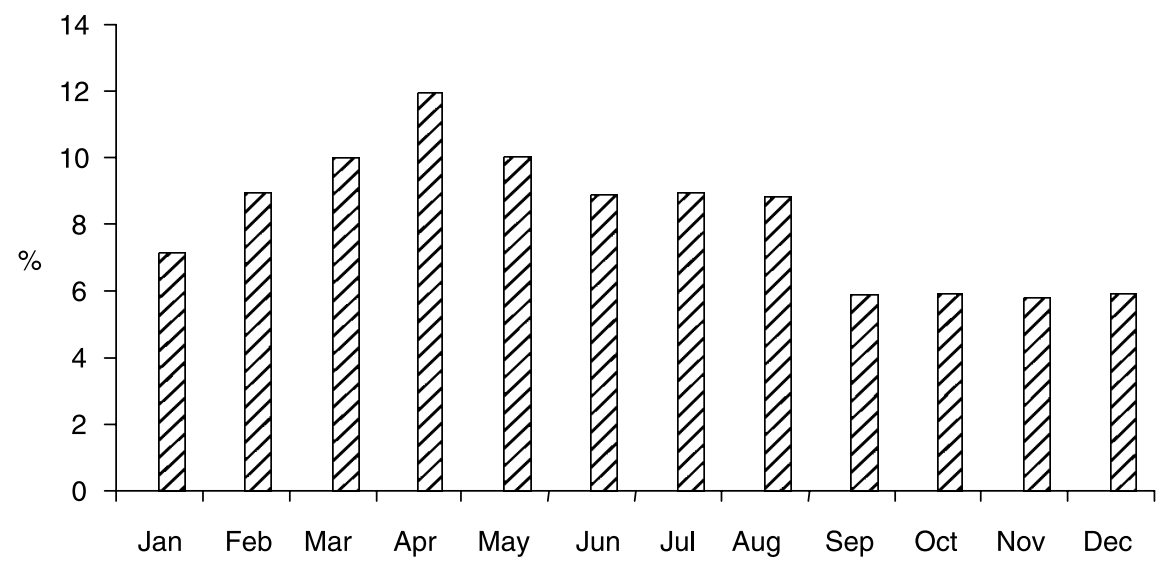

Figure 3 Seasonal variations (\% of the total annual production) in ovine meat production in $2004\left(4.4 \times 10^{6}\right.$ head) in France (source: Groupe d'économie du bétail (2006)). 
from late winter to early spring. This ensures maximal survival rate of the progeny in mammals because this period provides high food availability in these species (Ortavant et al., 1985). Similarly in many feral birds (partridge, quail, granivore birds), the nesting season starts in spring as it also corresponds to the period when food becomes available (onset of the reproductive or hatching season in insects, which are the main source of proteins for recently hatched chicks; period at which plant-derived feed becomes available; Sauveur (1988 and 1996)). In fish which are much more directly dependent on water temperature and to a lesser extent on photoperiodic conditions, spring is also the most commonly observed period for production of first-feeding fry in temperate zones as it corresponds to the period of increasing temperature and day length (Bromage et al., 2001). Young fry have increasing quantities of phytoplankton and zooplankton available for feeding during spring and the juveniles will benefit from a long period of growth during summer and thus be stronger for their first winter of life (Conover, 1992). This is the case of salmonids, which are extensively used in aquaculture. However, variability between fish species appears really very high as alevins, from other species reared under temperate climate, may be naturally released in winter as seen with Mediterranean seabass or seabream (Zohar et al., 1984), or in summer, with cyprinids (Billard, 1995) or turbot (Mugnier et al., 2000).

Thus, this highly adaptive reproductive activity is in many species part of the species-specific mechanism developed over millenariums to produce life strategies adapted to local geographic and climatic environments at the time of parturition. Examples of species-specific strategies include the very short breeding season of the mouflon (Santiago-Moreno et al., 2001), or the delayed implantation of fertilised ova in the roe deer, ferret and bison (in roe deer: fertilisation in July, implantation in December;
Thimonier and Semperé (1989)) and hibernation in the European hamster, European bear and hedgehog (Bronson, 1989, Canguilhem et al., 1988; Saboureau et al., 1991). While it is highly likely that many other strategies remain, at least in part, unknown, those expressed in mammalian species raised for meat and milk production have appeared, despite domestication, as highly predictive of the seasonal variations of their environment. One of the most striking adaptive mechanisms expressed in domesticated mammalian species is the adjustment of the reproductive period (ovulatory activity, sperm production) with the length of gestation so that a given species develops the best possible strategy to provide its progeny with optimal conditions for feed availability and climatic environment at the time of parturition. Thus, horses and sheep litter in spring but whilst mares present their maximum ovulatory activity during late winter and spring, in ewes it occurs during late summer and autumn (Figure 4). In fish pike, spawning occurs during the early spring in shallow weedy water that warms rapidly during the day, while cyprinids will spawn later in the year in already warm deeper ponds. It is obvious that these different predictive strategies, in which the timing of reproduction is precisely adjusted to the environment in order that births coincide with a favourable season for the progeny, constitute a key element of the adaptive mechanisms developed over time and so allow species to survive and proliferate under harsh conditions, i.e. when climatic variations of the environment (light, temperature, food availability) are very variable.

Although seasonality in reproduction is found in all vertebrate classes, some biological specificities may involve various seasonal requirements of energy for reproduction. Firstly, homeothermic mammals and birds require more energy for their basal metabolism than poikilothermic fish. Secondly, oviparous birds and fish need more energy than mammals during gametogenesis for oocyte vitellogenesis.

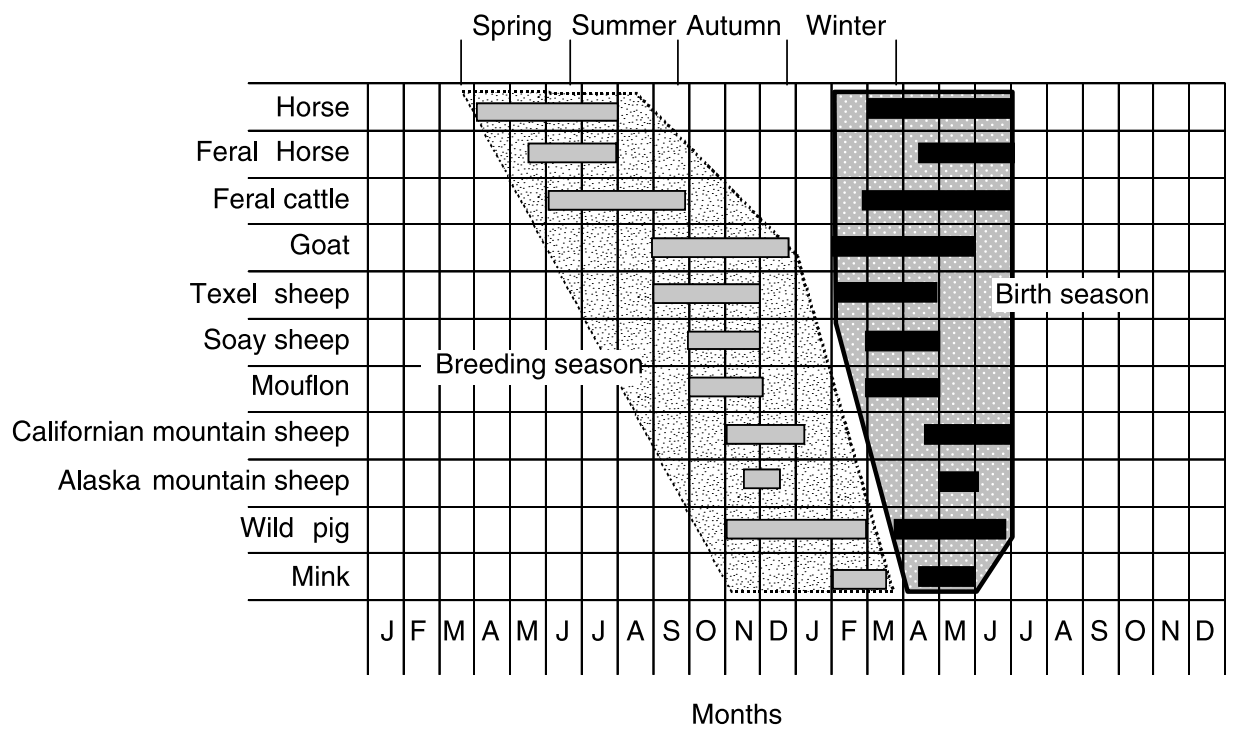

Figure 4 Timing of the annual reproductive cycle of some seasonal breeders. (adapted from Ortavant et al. (1985)). 
This is especially so in fish which release a large quantity of eggs because youth survival is very low in the natural aquatic environment. Finally, gestation (mammals) and parental care and feeding (mammals and birds), require more energy although this is not the case with farmed bony fish (except in some tilapias). These specific needs have different consequences in the timing of energy requirement and mobilisation for the success of reproduction.

\section{Seasonal variations of gonadal activity, sexual behaviour and littering in farm animals}

Alterations in reproductive activity are associated with alterations in gonadal activity and, as such, large species specific differences in both the timing and duration of gonadal activity can be seen. For example, the frequency of ovulations in unmated Alpine and Saanen dairy goats, even when maintained in excellent body condition, varies dramatically from 0 (March to September) to $100 \%$ (October to January) which means a long period of sexual rest, the anoestrous season (Figure 5). Oestrous behaviour is strongly associated with ovulatory activity in these breeds (Chemineau et al., 1992). Ile-de-France ewes behave in the same way but, during the anoestrous season, some females show isolated ovulations without associated behaviour (Thimonier and Mauléon, 1969), and in horses a majority of mares stop ovulations from December to May (Palmer and Driancourt, 1983).

In contrast to sheep and goats, dairy or beef cows, when not mated, do not stop ovulatory activity, an indication that they are potentially able to breed year round. Despite this, factors including the interactions between body condition and nutrition, the presence of a calf (if calving in winter) and photoperiodic rhythm synergistically converge to induce a strong seasonal pattern of the post-partum ovulatory activity in beef cattle characterised by a limited period of time for ovulations (Ingrand et al., 2003; Agabriel et al., 2004).

In males from the seasonal species cited above, spermatogenic activity and sexual behaviour do not stop but are also highly dependent on season. Thus in Soay rams, a primitive breed from north Scotland, testicular size (which reflects spermatogenic activity), plasma FSH and testosterone concentrations as well as sexual 'flush' and aggressive behaviour reach their maximum between August and November, the 'rut' season in this breed (Lincoln, 1979). In lle-de-France rams, testicular weight and sperm production per testis (directly measured at its output) vary from less than $200 \mathrm{~g}$ and 1 billion per day in March, to more than $300 \mathrm{~g}$ and 5 billion per day in September, respectively (Ortavant et al., 1985). Similarly, Alpine bucks display dramatic variations in sexual behaviour (0 to 1.5 matings in $10 \mathrm{~min}$ ), sperm individual motility (2.5 to 3.5 over 5 ) and fertilizing ability ( 20 to $70 \%$ of kiddings after Al) between the spring-summer and autumn-winter periods (Delgadillo et al., 1992). These variations are associated with deep changes in ejaculate volume and sperm concentration which, in this species showing a deleterious effect of seminal plasma on in vitro sperm survival, have important implications on semen technology. Stallions also show seasonal variations in sexual behaviour and sperm quality, the lowest season being in winter and the highest in spring-summer (Magistrini et al., 1987).

As previously mentioned, the intensity of seasonality of reproductive activity is highly variable between and within

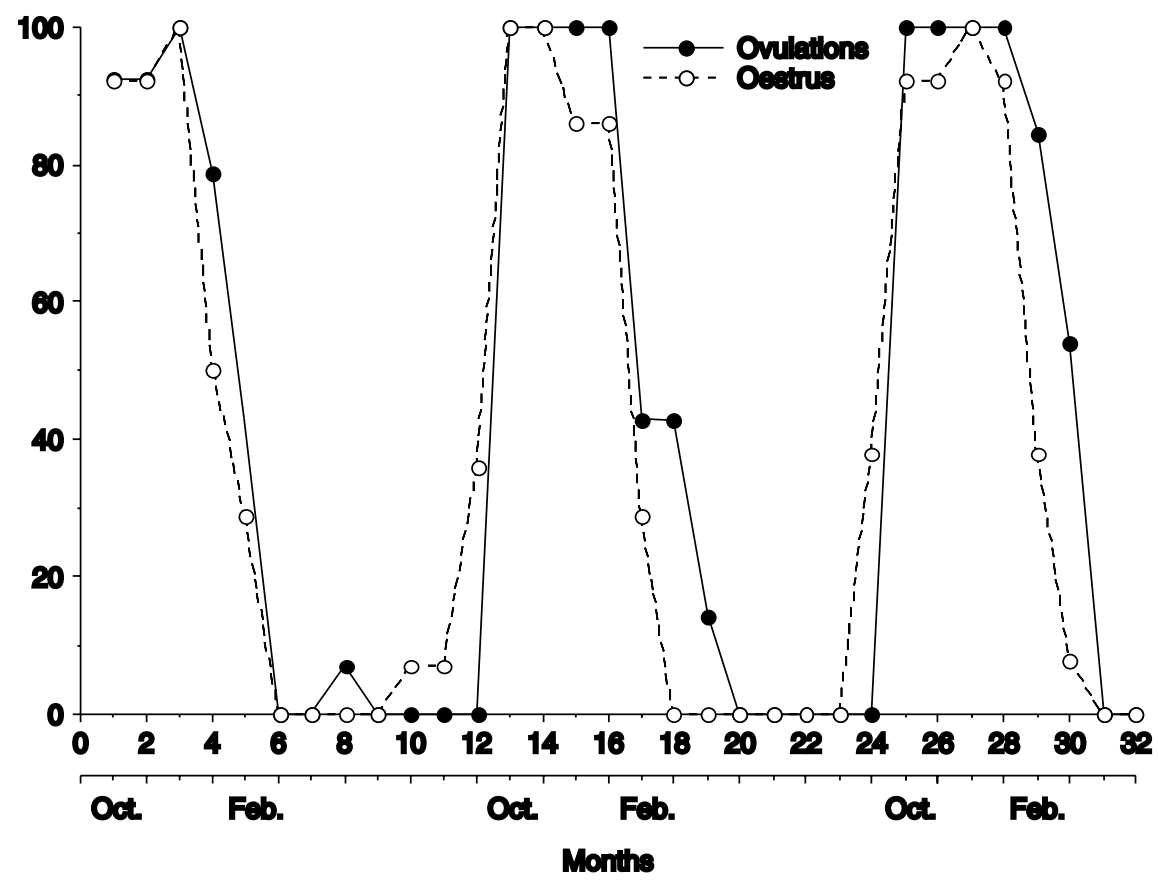

Figure 5 Seasonal variations of the occurrence of ovulations and oestrous behaviour in Alpine goats (adapted from Chemineau et al. (1992)). 
species. Thus, in fish, which are found at all latitudes, opportunistic strategists are more common in tropical latitudes and periodic strategists are more common in temperate and Arctic latitudes (Vila-Gispert et al., 2002).

In the Bovidae family, cows do not stop their ovulatory activity over the year while goats are in anoestrus for, depending on their genetic origin, 250 days or more. Similarly, domestic sows present moderate seasonal variations of their reproductive activity while wild sows completely stop completely in spring-summer.

Within a given species, it has long been established that the various breeds may express variable degrees of seasonality. For example, Texel and Soay ewes are highly seasonal, while Merino and Manchega ewes present more discrete expression of seasonality (Hafez, 1952; Santiago-Moreno et al., 2000). Breeds raised in more southern areas, especially in the subtropics and the tropics (north Africa, west Africa, West Indies, tropical Asia and the Americas) generally present low seasonality or cycle all the year round with no anovulatory period (Gonzalez-Stagnaro, 1983; Khaldi, 1984; Yenikoye, 1984; Chemineau, 1986; Mahieu et al., 1989). This is an interesting trait of these breeds for local farmers who can then organise the breeding season of their flock without expensive hormonal treatments. Unfortunately, a marked seasonality is expressed in these breeds when subjected to the wide photoperiodic variations and temperate climates of septentrional countries, thus constituting a major limitation to their extensive use in animal production systems in these countries (Chemineau et al., 2004).

However, in temperate breeds maintained under environmental conditions similar from which they originate, an intra-breed variability may also exist. In some species (sheep, goat), some reproductive traits including the onset, offset and duration of the breeding season were found heritable, therefore becoming candidates for genetic selection (Ricordeau, 1982; Quirke et al., 1986; Hanrahan, 1987; Smith et al., 1992; Al Shorepy and Notter, 1997). However these traits are quite difficult to measure at farm level because of their strong link with the female production cycle. An alternative approach could be to use more indirect traits such as the presence or absence of ovulatory activity in spring, a trait found to be heritable in Merino ewes (Hanocq et al., 1999).

The existence of a genetic basis for seasonality of reproduction also suggests control by a polymorphism of specific genes. In the Landaise grey goose, laying intensity (i.e. number of eggs laid per week by 100 females) varies from zero in January to $50 \%$ in April-May (Figure 6), and could also be genetically selected (Basso et al., 2006). The existence of a relationship between intensity of anovulation (presence/absence of ovulations) and the relative frequency of precise alleles of the melatonin receptor MT1 in Merino sheep was shown and suggests that it could be used for selecting animals on the presence of favourable alleles (Pelletier et al., 2000; Notter et al., 2003; Notter and Cockett, 2005). However, the genetic variability of seasonality, as it occurs for many other traits, is not dependent on the polymorphism of a single gene but on a variety of genes most of which still remain to be identified and assessed prior to any possible application in selection.

Fish show a very large diversity of reproductive strategies within many of their species (Jalabert, 2005). However, as a large quantity of energy is required during vitellogenesis to produce the millions of eggs containing the reserves for embryos, this process lasts several months under temperate climates (Jalabert, 2005). Thus, seasonal species of fish

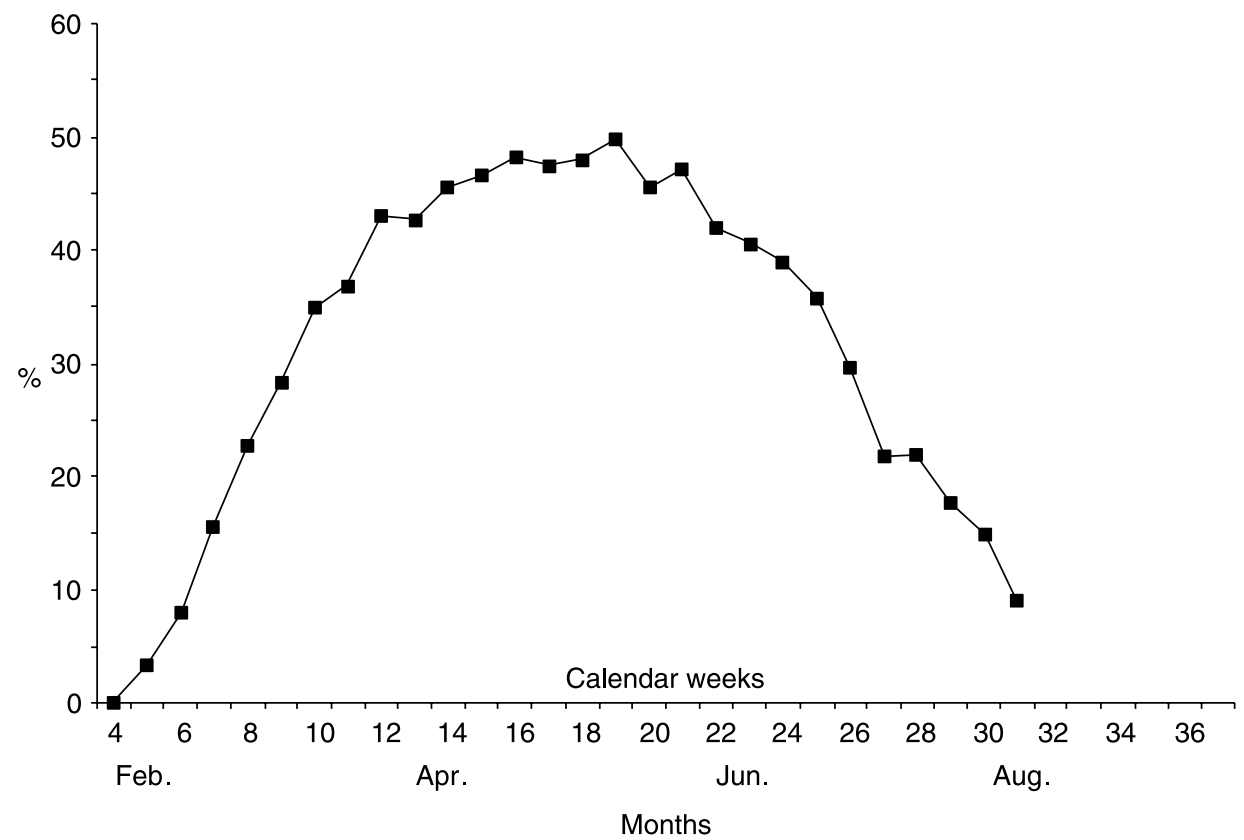

Figure 6 Laying intensity ( = number of eggs laid per week per 100 females) in the Landaise grey goose (adapted from Mialon-Richard et al. (2004)). 
usually show an annual sexual cycle where their spawning period occurs only once a year. During this period salmon, trout and carp spawn all their eggs at once. Other commercial fish species females are multi-spawners however, like common perch, turbot, halibut or cod. Here the reproductive period may last several weeks (McEvoy and McEvoy, 1992). In contrast to what is observed in domestic mammals, spermatogenic activity is usually completely stopped, for a vast majority of the year and starts at a specific season, producing synchronous waves of germinal cells (Maisse and Breton, 1996; Gomez et al., 1998). Breeders produce sperm during a long part of the spawning season and can be used several times for in vitro fertilisation. However the quality of the sperm may vary (Billard, 1986). Secondary sexual characters are not always well marked in fish, and they may only appear shortly before the breeding period. Pheromones, which regulate sexual behaviour, originate from hormones (prostaglandins and steroids; Stacey (2003)) involved in the regulation of the last stages of gametogenesis and of gametes release, and are thus only released into water during the breeding season.

Diversity in fish reproductive strategy involves diversity in the timing of fish spawning (Webb and McLay, 1996). Thus, it occurs in late autumn to winter in salmonids (Bromage et al., 1992), late winter to early spring in European sea bass, gilthead seabream (Zohar et al., 1984) and cod (Hansen et al., 2001), spring in Eurasian perch, (Migaud et al., 2002), red porgy (Kokokiris et al., 2001) and Atlantic halibut (Björnsson et al., 1998), or late spring to summer in turbot, (Mugnier et al., 2000) and carp (Billard, 1995). Embryonic development up to first-feeding fry depends on egg size and water temperature. Usually, this period is shorter in springsummer spawning species than in autumn-winter ones. Thus, eggs develop within several weeks in salmonids and only a few days in cyprinids. However, eggs from the European sea bass, which spawns during the cold season, develop within 8 days at $13^{\circ} \mathrm{C}$ (Saillant et al., 2001). Slowing down or speeding up the embryonic development and the growth of juveniles by adjusting water temperature and/ or feeding, can be one way for fish farmers to partly schedule their production., Genetic selection may also be used in some cases to extend the reproductive period: a high heritability has been found in rainbow trout for the date of spawning $\left(h^{2}=0.65\right.$; Su et al. (1997)) and several strains spawning at different seasons already exist for experimental or aquaculture purposes.

\section{Seasonality is a combination of endogenous circannual rhythms with the entraining effects of photoperiodic and temperature variations}

Thus a large proportion of farm vertebrates raised under temperate climates show seasonal variations in their gonadal activity and a precise timing in the year when females shed eggs to be fertilised by male spermatozoa. Within a specific species or breed, the so-called 'breeding season' appears very stable from one year to another, with fixed dates of onset and offset of female ovulatory activity and a period of maximum quantitative and qualitative sperm production. Even within-species or within-breed variability in these dates exists, the average timing of the breeding season in a calendar year is always the same from one year to another, thus allowing a maximum fit with the variations in the environment. This timing is due to complex but highly precise underlying physiological mechanisms which allow animals to 'locate' their breeding season over the year and express their sexual activity at the right time, synchronously between sexes and with external environmental factors.

In some species of mammals, birds and fishes, similarly to the circadian 'clock' (i.e. with a free-running period close to $24 \mathrm{~h}$ ) which generates endogenous circadian rhythms, a circannual 'rhythm', endogenous to animals, is likely to generate alternate periods of sexual activity with periods of sexual rest throughout the year. These alternate periods can be observed when animals are kept experimentally under constant photoperiodic regimens (constant short days, for example), over at least two consecutive years (mammals: Jansen and Jackson, 1993; Malpaux et al., 2001; Malpaux, 2006; birds: Gwinner, 2003; fish: Bromage et al., 2001). The physiological mechanisms underlying this circannual system remain largely unknown. Some information has been identified in two experimental models, rodents (Larkin et al., 2002) and domestic sheep (Lehman et al., 2002). The main part of the mechanism resides in the central nervous system and probably involves successive ability to alternately inhibit or stimulate the LH-RH neurons of the hypothalamus. Thyroid hormone T4 must be present at a constantly low plasma level for the expression of the endogenous rhythm (Billings et al., 2002). It probably acts in the pre-mammillary area of the posterior hypothalamus in ewes. Associated changes in neuronal plasticity, identified by changes in PSA-NCAM, have been demonstrated (Lehman et al., 2002). Similarly, changes in the expression and binding capacity of serotonergic receptor 5HT2A were observed in association with opposite stages of the endogenous rhythm (Chemineau et al., 2003). In ewes, this endogenous rhythm is timed by discrete signals given by external changes in photoperiod (Barrell et al., 2000).

The specific role of long days (LD) and short days (SD) in timing reproductive activity depends on species. In short-day breeders (i.e. animals which are fully sexually active during SD) like sheep and goats, SD are stimulatory and LD inhibitory of sexual activity. In contrast, SD inhibit while LD stimulate sexual activity in species sensitive to LD such as horses, mice and most poultry. These unique properties of the duration and variations of photoperiod to control reproductive activity in both sexes have, in practice, been of extensive use in farm animals (see below). However in mammals and birds subjected to a constant, normally gonado-stimulatory photoperiod, the day lengthspecific effect is not permanent. Animals «escape» and 
become 'refractory' to the prevailing photoperiod: SD are no longer stimulatory in sheep or inhibitory in mares, LD are no longer inhibitory in goats or stimulatory in mares, chicken and turkey. In fish, in which both photoperiod and temperature may interact to regulate seasonality, occurrence of refractoriness has also been reported, for example, from the middle of autumn to early winter, gonads do not develop in mummichog, even under adequate temperature and long day-length conditions (Shimizu, 2003). This refractoriness could conceptually be considered as merely expression of the circannual endogenous rhythm. It can be 'broken' by transferring animals into the opposite photoperiod: refractoriness to $S D$, which occurs naturally in sheep in late winter, is broken by 2 months of exposure to LD in December-January, allowing the efficiency of stimulatory SD to be restored. Thus, by subjecting animals to opposite photoperiods, it is possible to control seasonality of reproduction. This property is now commonly used in photoperiodic treatments applied on farms and/or in $\mathrm{Al}$ centres. The definition of what is really $L D$ and SD is not straightforward. For example, it is possible to define a threshold of photosensitivity based on the number of light hours per day, under which LD are stimulatory and below which SD are inhibitory (see reviews Malpaux et al. (1996) and Chemineau et al. (1996)). For example, in male turkeys, recent observations indicated that the threshold of sensitivity to photoperiod occurs between 0930 (non stimulatory) and 1030 (stimulatory hours of light/day; Blackault et al. (2006a and b)). In mammals and birds, the photoperiodic history of each individual should also be taken into account. Thus, it is now commonly accepted that SD are days shorter than the preceding ones, and that LD are days longer than the preceding ones. This property is interesting under field conditions: following a period of artificial long days, animals perceive SD even though natural day length is longer than $12 \mathrm{~h}$ of light per day. Another interesting property can be used under farm conditions to apply long days: the illumination of a specific phase of the night, the so-called 'photosensitive phase', generally situated 14 to $16 \mathrm{~h}$ after dawn, allows animals to perceive LD even though real LD are not applied (see reviews of Aupinel and Bonnet (1996) in snail, Sauveur (1988 and 1996) and De Reviers (1996) in birds, Maisse and Breton (1996) in fish, Malpaux et al. (1996) and Chemineau et al. (1996) in sheep and goats, and Guillaume (1996) in mares).

More generally, photoperiod, which entrains the endogenous circannual rhythms of reproduction, exerts its action through two different but complementary and dependent pathways by (a) synchronising the reproductive period between individuals of the same species and (b) by adjusting the phases of gonadal development with external natural conditions. It is noteworthy that circannual rhythms of photoperiod affect avian migrations by controlling the migratory direction in a seasonal manner (see review by Gwinner (2001)). In mammals, all the photoperiodic input is perceived exclusively through the eyes then transmitted via a synaptic pathway to the pineal gland, which transduces the photic signal into a chemical one by synthesising and secreting melatonin. Synthesised at night, mainly in the pineal gland in mammals, melatonin is delivered to the brain via the cerebrospinal fluid and to peripheral tissues by general circulation. To control reproductive activity in sheep, melatonin acts on the pre-mammillary hypothalamus in which it binds to specific receptors which stimulates, about 45 days after the onset of daily impregnation, the pulsatile activity of LHRH-LH which in turn will drive gonadal and behavioural sexual activities (review by Malpaux et al. (2001)). External melatonin can be given to 'mimic' SD and has been of practical use in sheep and goats to stimulate reproduction in spring. The situation is more complicated in fishes and birds which, at an impubertal stage, may directly perceive light through photoreceptors located in the brain and/or the pineal gland, for which the role of melatonin is not well understood because it probably acts on various parts of the organism (Sauveur, 1988 and 1996; Ekström and Meissl, 1997). In birds, the mechanisms involved in the processes of photoperiodic time measurement and of light transmission to the brain remains, in part, unexplained. Since the early observations of Rowan (1925), several hypotheses have been proposed to describe the precise and highly repeatable mechanism by which avian species perceive and measure the duration and variations of photoperiod to regulate their reproductive season. While extensive research has demonstrated that photoperiodic time measurement in mammals and birds is perceived through the circadian system (Benoit, 1935), indications now exist in birds that the median basal hypothalamus contains several major components involved in a specific response to photoperiod (Ball and Balthazart, 2003). In these species, light reaches encephalic receptors through several pathways including a direct transmission to the hypothalamus via the eye and the optic nerve or via the pineal gland or, perhaps also, via the Harderian gland. In addition, light which penetrates the skull to the extra-retinal photoreceptors is received by a photo-pigment (hypothetically rhodopsin) prior to its chemical transduction towards the hypothalamus (see review by Lewis and Perry (1995)). Even though not yet fully understood, the mechanisms involved in the processes of light transmission in birds do appear quite specific, perhaps due to the necessity, in many species, to adjust precisely their migratory behaviour to the onset and duration of their reproductive season.

Although, melatonin receptors have been reported in pike pituitary (Gaildrat and Falcón, 2000), the role of melatonin is more confusing in birds and fish, probably because, as stated earlier, it acts on various parts of the organism in these species. Not only sun but also moon light changes may be perceived by some coral fish species (Park et al., 2006). Besides in fishes, other aspects of reproductive biology such as sexual inversion might involve melatonin (Shi, 2005). It remains, however, that a circadian clock entrains the rhythm of melatonin synthesis at least in part 
if not in all non-mammalian vertebrates (Falcón, 1999). Such a circadian clock is itself adjustable by photoperiod (Ceinos et al., 2005).

In addition to photoperiod, temperature may also play an important role in the reproductive seasonality of fishes, birds and, more generally, in a number of other poïkilotherm vertebrates. As an example, an adult common carp may spawn four or five times per year if maintained at 20 to $22^{\circ} \mathrm{C}$ (Horvath, 1986). Besides temperature per se, a quite common factor is the occurrence of temperature $x$ photoperiod interactions even in species renowned as photoperiod-dependent (fishes: Breton and Billard, 1977; Bromage et al., 2001; birds: Kato and Konishi, 1968). In some species, like the Eurasian perch, a proper photothermal regime is necessary to obtain a normal gametogenesis (Fontaine et al., 2006).

Important progress has been made in the last few decades to understand the main components of the underlying physiological mechanisms that control seasonality of reproduction in vertebrates. The existence of an endogenous circannual mechanism entrained by photoperiodic variations remains to be proved. It is thought that the retinal photoreceptors modulate pineal melatonin secretion and are the common 'knots' of the network, whatever the species. However, the precise location of this circannual mechanism remains to be discovered, as does whether it is, or is not, a 'clock', and how melatonin acts to drive the LHRH system. Of course, large differences exist between species and in many their specificities remain to be extensively studied.

Nevertheless, the numerous experiments done before entering the 'black box' of the brain, using only photoperiodic variations have led to proposals to farmers and artificial insemination (Al) centres for specific light schemes which may be able to control seasonality of reproduction of their animals.

\section{Using artificial photoperiodic treatments to control seasonality of reproduction and milk production in farm animals}

Over the past few decades, photoperiodic treatments have been of practical use in a variety of farm animal species ranging from meat and egg-type poultry (Lewis and Perry, 1995) to mammals (Malpaux et al., 1996) and from fish (Maisse and Breton, 1996) to snails (Aupinel and Bonnet, 1996) with the ultimate objective of providing consumer's accessibility to fresh animal products of various origins all year round.

The enormous development of intensive poultry production world-wide is, in part, the consequence of longdefined light regimes applicable to each period of the breeder's life in which the duration and variations of the photoperiod, as well as light intensity and adequate wavelength (through light source), can be adequately controlled from hatching to the end of the reproductive season (Sauveur, 1996; De Reviers, 1996). Over the past 25 to 30 years, the majority of layer-type chickens for table egg production have been subjected to intermittent lighting regimes (i.e. providing more than one light and dark period per day) necessitating dark housing. Such regimes, in which a 24-h cycle is fractioned in several alternate light and dark periods may, depending on the category of programme used (asymmetrical, symmetrical, biomittent...) result in increased laying performance, egg weight and/or feed consumption (Lewis and Perry, 1995; Sauveur, 1996). In poultry meat-type breeds, a specific adjustment of the external environment (light, temperature) in male and female breeders has also been of prime interest in developing Al programmes. As an example, egg fertility in artificially inseminated flocks depends on the timing of semen deposition with regards to the period of oviposition, itself directly under the control of the photoperiod (Brillard, 2003). Changes currently underway to adjust egg-type production systems to EC regulations along with the rapid evolution of phenotypes in meat-type strains has resulted in the necessary re-appraisal of environmental (light) and nutritional practices to properly adjust to the new requirements necessitated by these changes.

In fishes, where the number of sires is reduced, different photoperiodic schemes can be applied to induce an out-ofseason spawning. The principles of these treatments are those described earlier, a succession of LD and SD. In the rainbow trout, for example, the succession of 2 months $L D$ immediately after the usual spawning period followed by 4 months SD, induces a new spawning season about 6 months after the first one (Figure 7). It is also possible to delay the onset of sexual maturation which could be of interest in focusing all the metabolism of the animal on growth and not on reproduction (Maisse and Breton, 1996; Bromage et al., 2001). Whatever the photoperiodic treatment, temperature should be adjusted properly. Thus, an off-season spawning of rainbow trout in summer, needs to keep water temperature at least below $15^{\circ} \mathrm{C}$ (Maisse and Breton, 1983). Finally, even though results are globally satisfactory, there is still inter-individual variability in terms of gametes quality, especially when occurrence of malformations are accurately looked for (Bonnet et al., 2006). This variability might be related to the heterogeneity of gametogenic stages within breeders at the beginning of the photoperiodic manipulation.

In mammals, photoperiodic treatments have been of practical interest for controlling seasonal reproduction essentially in sheep, goats and horses.

In sheep and goat Al centres, now equipped with dark housing, alternate light regimes with 1 month LD and 1 month SD allow permanent high semen production in rams and bucks, with no seasonal variations in sperm quality. Currently, all bucks of the French national genetic improvement scheme (about 70 per year) are permanently treated with rapid alternation LD-SD, which allows increased $\mathrm{Al}$ dose production $(+40 \%)$ per buck and per year (Delgadillo et al., 1993) and reduced duration of the breeding period of males (culling after 18 months of 


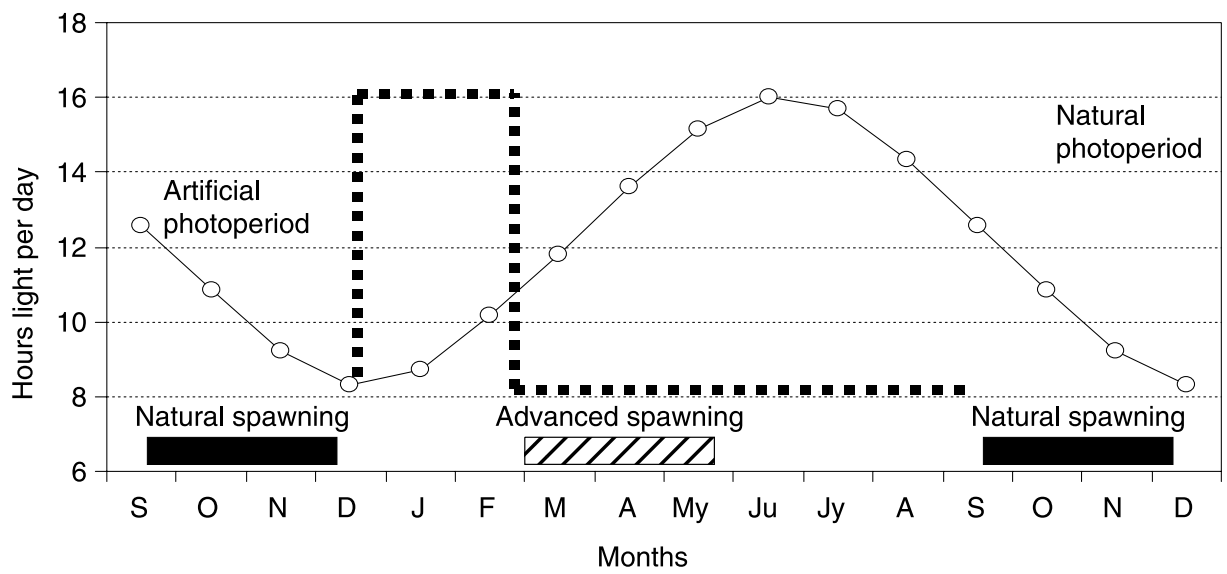

Figure 7 Spawning times of rainbow trout exposed to natural (black bars) or stimulatory long-short (striped bar) photoperiods. (adapted from Maisse and Breton (1996)).

production, or about 18 months earlier that those maintained under natural photoperiod). In other Al centres which do not require permanent production of semen doses, rams raised in open barns are subjected to 2 to 3 months extra 'LD' (from December to February) followed either by return to natural photoperiod, or by subcutaneous treatment with melatonin implants to mimic SD ('SD') (Figures 8 and 9). This 'LD'-'SD' treatment stimulates semen output in quantity and quality in spring, thus mimicking the normal sexual season which, itself normally lasts 2 to 3 months (Malpaux et al., 1995).

On goat farms, (always equipped with open barns) males and females are subjected to the second type of treatment performed in Al centres ('LD'-'SD'). It is always associated with a 'buck effect' (introduction of treated bucks for 45 days, after 35 to 75 'SD') in order to induce ovulations and oestrous behaviour. Under such conditions, out-of-season fertility and prolificacy can be kept at high levels ( $>75 \%$ kidding rate with about two kids per kidding) (Chemineau et al., 1996). In subtropical conditions and for local breeds of the subtropics where seasonality is less marked than those raised under temperate latitudes, the treatment of females may not be necessary. When the LD treatment is applied only in bucks used for the 'buckeffect', the percentages of females ovulating and fertility after natural mating are high (Delgadillo et al., 2002 and 2004).

In ewes, a majority of out-of-season lambings are still obtained using 'classical' hormonal treatments (FGA sponges + eCG) but the frequency of utilisation of melatonin implants is increasing, especially in Mediterranean countries. Implant use also increases fertility and prolificacy. Overall, an increase of 0.20 lamb per ewe treated per year has been almost always observed, such increase originating from increased proportions of twins rather than triplets (Chemineau et al., 1996).

Photoperiodic treatments are also applied in mares to advance the annual breeding season and to give foals a decisive age-related advance when competing with their contemporaries born the same year. This is generally performed by exposing mares to LD or pseudo LD during autumn. Such treatments allow mares to be fertilised about 2 months earlier than females kept under a natural photoperiod (Guillaume, 1996).

Photoperiodic treatments are now used in both sexes of nearly all farm species to control seasonal reproduction. Whatever the species, they use common properties of alternations between inhibitory and stimulatory photoperiods, where durations are adapted to the species and sex. When using pure light treatments (without melatonin), especially when applied in open barns, they could be considered as non-invasive which fully respects animal welfare considerations. It is very probable that these photoperiodic treatments will be used more extensively in the future as livestock production systems strive to be more sustainable.

As explained in the first section of this review, seasonal variations in the quantity (milk yield) and quality (fat and protein content, somatic cell count) of dairy milk production are partly due to direct effects of day length on milk production and composition and/or on the general metabolism of dairy females. Long day length has been shown to stimulate milk production during lactation but to impair milk fat in cattle (Peters et al., 1978 and 1981; Stanisiewsky et al., 1985; Dahl et al., 2000 and Dahl and Petitclerc, 2003), sheep (Bocquier et al., 1984, 1990 and 1997) and goats (Delouis and Mirman, 1984). In contrast, short days, when applied during lactation, have a negative effect on milk production per se but increase the fat and protein contents of milk.

Interestingly, dairy heifers subjected to long days during their pre-pubertal period tended to produce more milk during the first lactation when maintained under the natural variations of photoperiod in regions of moderate latitudes in the northern hemisphere (Rius and Dahl, 2006). On the contrary, cows subjected to short days during their dry period, produce more milk during the subsequent lactation when maintained under the natural variations of photoperiod in regions of moderate latitudes in the northern hemisphere 
Light- proof building:

(a)

(b)

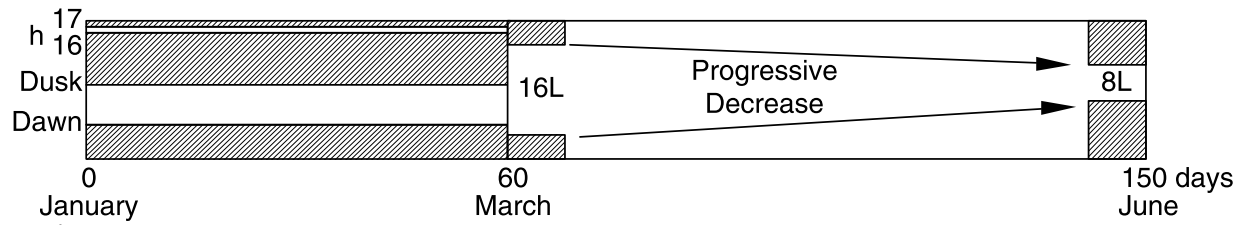

(c)
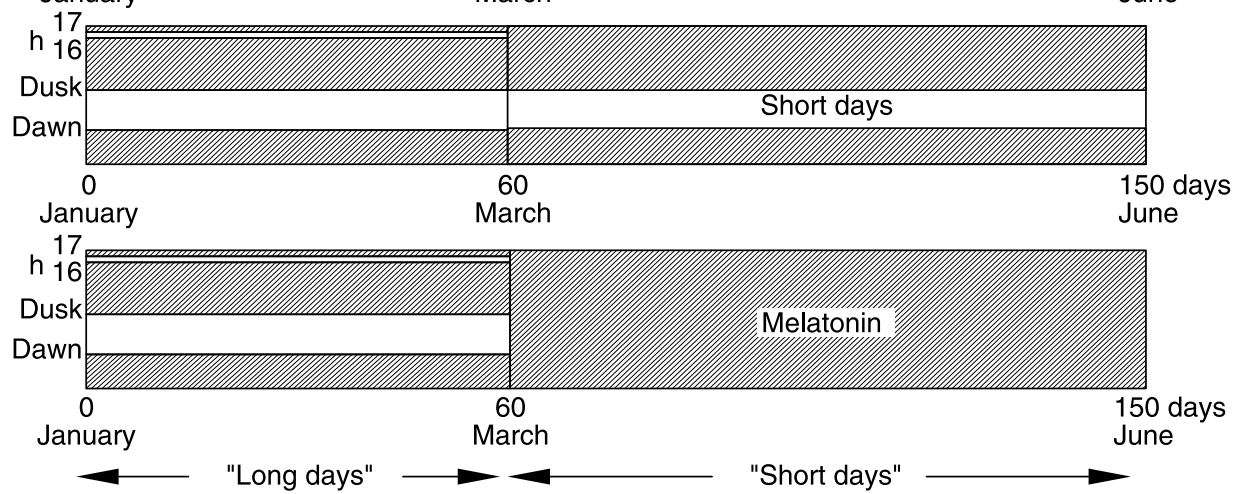

Open barns:

(d)

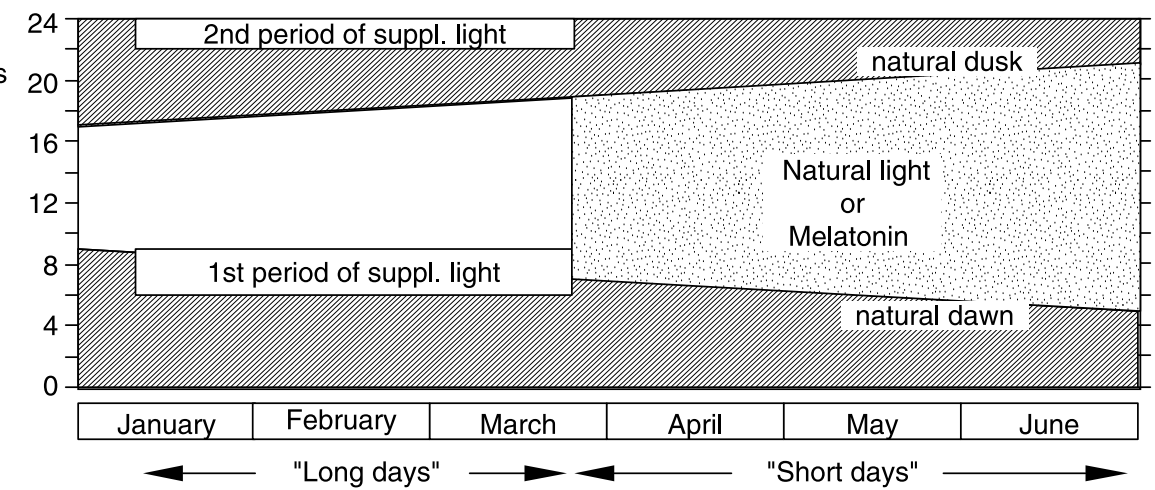

Figure 8 Photoperiodic treatments to control sexual activity in small ruminants raised in closed or open barns (adapted from Chemineau et al. (1996)).

(Auchtung et al., 2005). These effects cause a modulation of milk secretion at the mammary gland level, probably via pituitary hormones like prolactin and its associated recep-

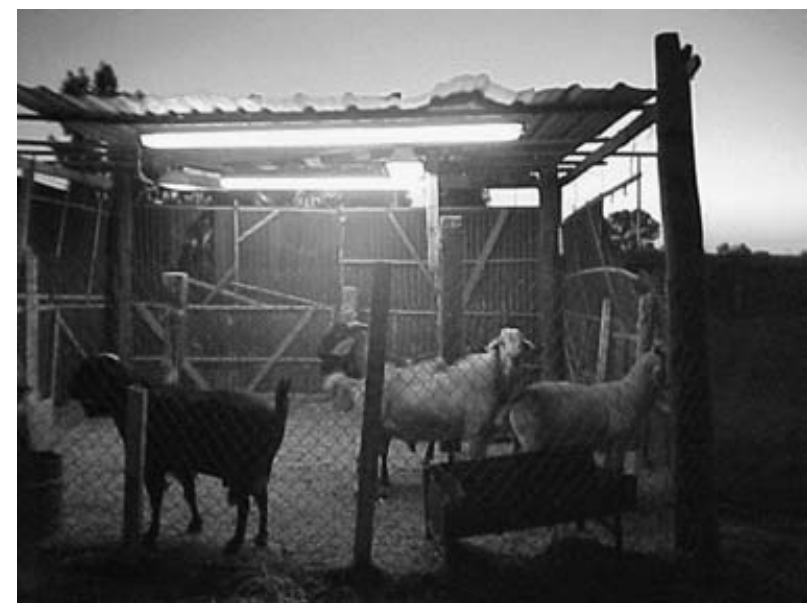

Figure 9 Open barn used for photoperiodic treatment of bucks in the Mexican subtropics (with the courtesy of J.A. Delgadillo, CIRCA Univ. A. Narro, Coahuila, Mexico). tors in the mammary tissue (Auchtung et al., 2005) but also via a general orientation of the metabolic routes under photoperiodic entrainment (Bocquier et al., 1998; Faulconnier et al., 2001; Chilliard and Bocquier, 2000; Chilliard et al., 2005). Photoperiod has also been shown to modify the general immune system in dairy cattle (Auchtung et al., 2004). To our knowledge, these photoperiodic manipulations of milk production in dairy cattle are widely used nowadays in USA/Canada, where over $30 \%$ of producers consistently report using long days in their herds.

\section{Conclusion}

The seasonality of animal products release is more the consequence of interactions between the natural endogenous rhythmicity of animals and environmental constraints than a deliberate choice of the farmer to produce at a definite season. In most seasonal species and breeds involved in these productions, specific photoperiodic treatments derived, at least in part, from the cumulative knowledge of physiological mechanisms involved in the control of the reproductive function, have progressively been proposed to 
overcome the problem raised by the seasonal availability of reproduction-derived products. In mammals, such treatments should be taken as an interesting alternative to classical hormonal treatments in a general context of reduction of hormonal utilisation in more sustainable animal production systems.

The existence of strong genetic bases for seasonality of reproductive activity in the main farm animal species should be further explored to propose selection criteria and/or gene markers accessible to primary breeder and producer organisations willing to reduce seasonality in their flocks.

\section{Acknowledgements}

The authors wish to thank Mr Mike Steele for his corrections of the manuscript.

\section{References}

Agabriel J, Blanc F, Egal D and Dhour P 2004. Influences combinées de la saison de mise bas et de l'exposition au taureau sur la venue en cyclicité de vaches Charolaises. Rencontres Recherches Ruminants Paris 8-9 déc. 11, 398

Al-Shorepy SR and Notter DR 1997. Response to selection for fertility in a fall-lambing sheep flock. Journal of Animal Science 75, 2033-2040.

Auchtung TL, Salak-Johnson JL, Morin DE, Mallard CC and Dahl GE 2004. Effect of photoperiod during the dry period on cellular immune function of dairy cows. Journal of Dairy Science 87, 3683-3689.

Auchtung TL, Rius AG, Kendall PE, McFadden TB and Dahl GE 2005. Effect of photoperiod during the dry period on prolactin, prolactin receptor, and milk production in dairy cows. Journal of Dairy Science 88, 121-127.

Aupinel P and Bonnet JC 1996. Influence de la photopériode sur l'activité saisonnière de l'escargot Petit-gris (Helix aspersa Müller). Effet spécifique sur la croissance et la reproduction. Productions Animales 9, 79-83.

Balasse $M$, Smith AB, Ambrose SH and Leigh SR 2003. Determining sheep birth seasonality by analysis of tooth enamel oxygen isotope ratios: The Late Stone Age site of Kasteelberg (South Africa). Journal of Archaeological Science 30, 205-215.

Balasse $M$, Tresset A and Ambrose SH 2006. Stable isotope evidence $\left(\partial^{13} C\right.$, $\left.\partial^{18} 0\right)$ for winter feeding on seaweed by Neolithic sheep of Scotland. Journal of Zoology 270, 170-176.

Ball GF and Balthazart J 2003. Birds return every spring like clockwork, but where is clock? Endocrinology 144, 3739-3741.

Barrell GK, Thrun LA, Brown ME, Viguie C and Karsch FJ 2000. Importance of photoperiodic signal quality to entrainment of the circannual reproductive rhythm of the ewe. Biology of Reproduction 63, 769-774.

Basso B, Mialon-Richard MM, Dubos F, Bernadet MD, Marie-Etancelin C, Guy $G$ and Brun JM 2006. Relation génétique entre caractères de reproduction et caractères de gavage chez l'oie landaise en conditions lumineuses contrôlées. $7^{\text {èmes }}$ Journées de Recherche sur les Palmipèdes à Foie Gras. Arcachon 18/19 Octobre. p 21-24

Benoit J 1935. Activation sexuelle obtenue chez le canard par l'éclairement artificiel pendant la période de repos génital. Comptes Rendus de l'Académie des Sciences Paris 199, 1671-1673.

Billard R 1986. Spermatogenesis and spermatology of some teleost fish species. Reproduction Nutrition Development 26, 877-920.

Billard R 1995. Les carpes, biologie et élevage. INRA Editions, Paris, pp. 387.

Billings HJ, Viguie C, Karsch FJ, Goodman RL, Connors JM and Anderson GM 2002. Temporal requirements of thyroid hormones for seasonal changes in $\mathrm{LH}$ secretion. Endocrinology 143, 2618-2625.

Björnsson BT, Halldórsson O, Haux C, Norberg B and Brown CL 1998. Photoperiod control of sexual maturation of the Atlantic halibut (Hippoglossus hippoglossus): plasma thyroid hormone and calcium levels. Aquaculture 166, 117-140.
Bocquier F, Mirman B and Delouis C 1984. Influence de la photopériode sur les performances de la brebis pendant la gestation et la lactation. $9^{\text {èmes }}$ Journées de la Recherche Ovine et Caprine, Paris, ed. ITOVIC-SPEOC, pp. 325-351

Bocquier F, Kann G and Thériez M 1990. Relationships between secretory patterns of growth hormone, prolactin and body reserves and milk yield in dairy ewes under different photoperiod and feeding conditions. Animal Production 51, 115-125.

Bocquier F, Ligios S, Molle $G$ and Casu S 1997. Effets de la photopériode sur la production, la composition du lait et sur les consommations volontaires chez la brebis laitière. Annales de Zootechnie 46, 427-438.

Bocquier F, Bonnet M, Faulconnier Y, Guerre-Millo M, Martin P and Chilliard $Y$ 1998. Effects of photoperiod and feeding level on perineral adipose tissue metabolic activity and leptin synthesis in the ovariectomized ewe. Reproduction Nutrition Development 38, 489-498.

Bonnet E, Fostier A and Bobe J 2006. Characterization of rainbow trout egg quality: a case study using four different breeding protocols, with emphasis on the incidence of embryonic malformations. Theriogenology (in press) Available online 21 November 2006.

Breton B and Billard R 1977. Effects of photoperiod and temperature on plasma gonadotropin and spermatogenesis in the rainbow trout, Salmo gairdneri Richardson. Annales de Biologie Animale, Biochimie, Biophysique 17, 1-10.

Brillard JP 2003. Practical aspects of fertility in poultry. World's Poultry Science Journal 59, 441-446.

Bromage N, Porter M and Randall C 2001. The environmental regulation of maturation in farmed finfish with special reference to the role of photoperiod and melatonin. Aquaculture 197, 63-98.

Bromage N, Jones J, Randall C, Thrush M, Davies B, Springate J, Duston J and Barker G 1992. Broodstock management, fecundity, egg quality and the timing of egg production in the rainbow trout. Aquaculture 100, 141-166.

Bronson FH 1989. Mammalian reproductive biology. University of Chicago Press Ltd, Chicago and London.

Canguilhem B, Vaultier JP, Pévet P, Coumaros G, Masson-Pévet M and Bentz I 1988. Photoperiodic regulation of body mass, food intact, hibernation and reproduction in intact and castrated male European hamsters, Cricetus cricetus. Journal of Comparative Physiology-A. 163, 549-557.

Ceinos RM, Rábade S, Soengas JL and Míguez JM 2005. Indoleamines and 5 -methoxyindoles in trout pineal organ in vivo: daily changes and influence of photoperiod. General and Comparative Endocrinology 144, 67-77.

Chemineau P 1986. Sexual behaviour and gonadal activity during the year in the tropical Creole meat goat. I. Female oestrous behaviour and ovarian activity. Reproduction Nutrition Development 26, 441-452.

Chemineau P, Daveau A, Cognie Y, Aumont G and Chesneau D 2004. Seasonal ovulatory activity exists in tropical Creole female goats and Black Belly ewes subjected to a temperate photoperiod. BioMedCentral Physiology 4, 12 (27 Aug 2004) (http://www.biomedcentral.com/ 1472-6793/4/12)

Chemineau P, Daveau A, Maurice F and Delgadillo JA 1992. Seasonality of oestrus and ovulation is not deeply modified by submitting Alpine goats to a tropical photoperiod. Small Ruminant Research 8, 299-312.

Chemineau P, Daveau A, Pelletier J, Malpaux B, Karsch FJ and Viguie C 2003. Changes in the $5-\mathrm{HT}_{2 \mathrm{~A}}$ receptor system in the pre-mammillary hypothalamus of the ewe are related to regulation of $\mathrm{LH}$ pulsatile secretion by an endogenous circannual rhythm. BioMedCentral Neuroscience 4, 1 (http://www. biomedcentral.com/1471-2202/4/1)

Chemineau P, Malpaux B, Pelletier J, Leboeuf B, Delgadillo JA, Deletang $F$, Pobel T and Brice G 1996. Emploi des implants de mélatonine et des traitements photopériodiques pour maîtriser la reproduction saisonnière chez les ovins et les caprins. Productions Animales 9, 45-60.

Chilliard $Y$ and Bocquier $F$ 2000. Direct effects of photoperiod on lipid metabolism, leptin synthesis and milk secretion in adult sheep. In Ruminant hysiology: digestion, metabolism, growth and reproduction (ed. PB Cronjé), pp. 205-223, CAB International, Wallingford, UK.

Chilliard Y, Delavaud C and Bonnet M 2005. Leptin expression in ruminants: nutritional and physiological regulations in relation with energy metabolism. Domestic Animal Endocrinology 29, 3-22.

Conover DO 1992. Seasonality and the scheduling of life history at different latitudes. Journal of Fish Biology 41, (Suppl. B) 161-178. 
Coulon JB, Chilliard Y and Rémond B 1991. Effets du stade physiologique et de la saison sur la composition chimique du lait de vache et des caractérisitiques technologiques. Productions Animales 4, 219-228.

Dahl GE, Buchanan BA and Tucker HA 2000. Photoperiodic effects on dairy cattle: a review. Journal of Dairy Science 83, 885-893.

Dahl GE and Petitclerc D 2003. Management of photoperiod in the dairy herd for improved production and health. Journal of Animal Science 81, (Suppl. 3) 11-17.

De Reviers M 1996. Photopériodisme, développement testiculaire et production de spermatozoïdes chez les oiseaux domestiques. Productions Animales 9, 35-44.

Delgadillo JA, Fitz-Rodriguez G, Duarte G, Veliz FG, Carrillo E, Flores JA, Vielma J, Hernandez $\mathrm{H}$ and Malpaux B 2004. Management of photoperiod to control caprine reproduction in the subtropics. Reproduction Fertility Development 16, 471-478.

Delgadillo JA, Flores JA, Veliz FG, Hernandez HF, Duarte G, Vielma J, Poindron $P$, Chemineau $P$ and Malpaux B 2002. Induction of sexual activity in lactating anovulatory female goats using male goats treated only with artificially long days. Journal of Animal Science 80, 2780-2786.

Delgadillo JA, Leboeuf B and Chemineau P 1992. Abolition of seasonal variations in semen quality and maintenance of sperm fertilizing ability by short photoperiodic cycles in he-goats. Small Ruminant Research 9, 47-59.

Delgadillo JA, Leboeuf B and Chemineau P 1993. Maintenance of sperm production in bucks during a third year of short photoperiodic cycles. Reproduction Nutrition Development 33, 609-617.

Delouis C and Mirman B 1984. Influence de la durée quotidienne d'éclairement sur la production laitière de la chèvre. $9^{\text {èmes }}$ Journées de la Recherche Ovine et Caprine, Paris, Ed. ITOVIC-SPEOC, 352-360.

Ekström P and Meissl H 1997. The pineal organ of teleost fishes. Reviews in Fish Biology and Fisheries 7, 199-284.

Falcón J 1999. Cellular circadian clocks in the pineal. Progress in Neurobiology 58, 121-162.

Faulconnier Y, Bonnet M, Bocquier F, Leroux $C$ and Chilliard Y 2001. Effects of photoperiod and feeding level on adipose tissue and muscle lipoprotein lipase activity and mRNA level in dry non-pregnant sheep. British Journal of Nutrition 85, 299-306.

Fontaine $\mathrm{P}$, Pereira C, Wang N and Marie M 2006. Influence of pre-inductive photoperiod variations on Eurasian perch Perca fluviatilis broodstock response to an inductive photothermal program. Aquaculture 255, 410-416.

Gaildrat $P$ and Falcón J 2000. Melatonin receptors in the pituitary of a teleost fish: mRNA expression, 2-[I-125]iodomelatonin binding and cyclic AMP response. Neuroendocrinology 72, 55-66.

Groupe d'économie du bétail 2006. Institut de I'Elevage d'après SCEES. Pâtre 531, 12-13.

Gomez JM, Loir M and Le Gac F 1998. Growth hormone receptors in testis and liver during the spermatogenetic cycle in rainbow trout (Oncorhynchus mykiss). Biology of Reproduction 58, 483-491.

Gonzalez-Stagnaro C 1983. Comportamiento reproductivo de las razas locales de rumiantes en el tropico americano. In Reproduction des ruminants en zone tropicale (ed. P Chemineau, D Gauthier and J Thimonier), pp. 1-84, INRA Publications 20, Versailles France.

Guillaume D 1996. Action de la photopériode sur la reproduction des équidés. Productions Animales 9, 61-69.

Gwinner E 2001. Bird migration: its control by endogenous clocks. In Frontiers of life, vol. 4, the living world (ed. D Baltimore), pp. 193-206, Academic Press, New York.

Gwinner E 2003. Circannual rhythms in birds. Current Opinion in Neurobiology 13, 770-778.

Hafez ESE 1952. Studies on the breeding season and reproduction of the ewe. Journal of Agricultural Science 42, 189-265.

Hanocq E, Bodin L, Thimonier J, Teyssier J, Malpaux B and Chemineau P 1999. Genetics parameters of spontaneous spring ovulatory activity in Merinos d'Arles sheep. Genetic Selection Evolution 31, 77-90.

Hanrahan JP 1987. Genetic variation in seasonal reproduction in sheep Proceedings of the 38th annual meeting of the European Association for Animal Production, Lisbon, Portugal, September 28 October 1, p. 14
Hansen T, Karlsen Ø, Taranger GL, Hemre G-I, Holm JC and Kjesbu OS 2001. Growth, gonadal development and spawning time of Atlantic cod Gadus morhua reared under different photoperiods. Aquaculture 203, 51-67.

Horvath L 1986. Carp oogenesis and the environment. In Aquaculture of Cyprinids (ed. R Billard and J Marcel), pp. 109-117, INRA Edition, Paris.

Ingrand S, Cournut S, Dedieu B and Antheaume F 2003. La conduite de la reproduction du troupeau de vaches allaitantes: modélisation des prises de décision. Productions Animales 16, 263-270.

Jalabert B 2005. Particularities of reproduction and oogenesis in teleost fish compared to mammals. Reproduction Nutrition Development 45, 261-279.

Jansen HT and Jackson GL 1993. Circannual rhythms in the ewe: patterns of ovarian cycles and prolactin secretion under two different constant photoperiods. Biology of Reproduction 49, 627-634.

Kato $M$ and Konishi T 1968. The effect of light and temperature on the testicular growth of the Japanese quail. Poultry Science 47, 1052-1056.

Khaldi G 1984. Variations saisonnières de l'activité ovarienne, du comportement d'oestrus et de la durée de l'anoestrus post-partum des femelles ovines de race Barbarine: influence du niveau alimentaire et de la présence du mâle. $\mathrm{PhD}$ thesis, University of Montpellier, France.

Kokokiris L, Le Menn F, Kentouri M, Kagara M and Fostier A 2001. Seasonal cycle of gonadal development and plasma levels of vitellogenin of the red porgy, Pagrus pagrus (Teleostei, Sparidae). Marine Biology 139, 549-559.

Larkin JE, Jones J and Zucker I 2002. Temperature dependence of gonadal regression in Syrian hamsters exposed to short day lengths. American Journal of Physiology, Regulatory Integrative and Compared Physiology 282, R744-R752.

Lehman MN, Coolen LM, Goodman RL, Viguie C, Billings HJ and Karsch FJ 2002. Seasonal plasticity in the brain: the use of large animal models for neuroanatomical research. Reproduction Supplement 59, 149-165.

Lewis PD and Perry GC 1995. Effects of lighting on reproduction in poultry. In Poultry production, (c) production system approach, World Animal Science (ed. X. Neimann-Sorensen and X. Tribe) 16, 359-385

Lincoln G 1979. Photoperiodic control of seasonal breeding in the ram: participation of the cranial sympathetic nervous system. Journal of Endocrinology 82, 135-147.

McEvoy A and McEvoy J 1992. Multiple spawning in several commercial fish species and its consequences for fisheries management, cultivation and experimentation. Journal of Fish Biology 41, (suppl. B) 125-136.

Magistrini M, Chanteloube P and Palmer E 1987. Influence of season and frequency of ejaculation on production of stallion semen for freezing. Journal of Reproduction and Fertility Supplement 35, 127-133.

Mahieu $M$, Jego $Y$, Driancourt MA and Chemineau $P$ 1989. Reproductive performances of Creole and Black-Belly ewes in the West Indies. A new major gene controlling ovulation rate? Animal Reproduction Science 19, 235-243.

Maisse $G$ and Breton B 1983. Production estivale d'œufs de truite par le contrôle photopériodique de la date de ponte. La Pisciculture Française 71, 25-30.

Maisse $\mathrm{G}$ and Breton B 1996. Contrôle photopériodique de la reproduction chez les salmonidés. Productions Animales 9, 71-77.

Malpaux B 2006. Seasonal regulation of reproduction in mammals. In Knobil and Neill's Physiology of Reproduction, third edition (ed. JD Neill), pp. 22312281. Elsevier, Amsterdam.

Malpaux B, Maurice-Mandon F, Daveau A and Chemineau P 1995. Utilisation de la lumière et de la mélatonine pour la maîtrise de la reproduction des ovins et des caprins. Rencontres Recherches Ruminants Paris 13-14 déc. 2, 379-386

Malpaux B, Migaud M, Tricoire H and Chemineau P 2001. Biology of mammalian photoperiodism and the critical role of the pineal gland and melatonin. Journal of Biological Rhythms 16, 336-347.

Malpaux B, Viguie C, Thiery JC and Chemineau P 1996. Contrôle photopériodique de la reproduction. Productions Animales 9, 9-23.

Mialon-Richard MM, Brun JM, Dubos F, Guy G and Sellier N 2004. Caractéristiques de la ponte de l'oie landaise en premier cycle sous programme lumineux. $6^{\text {èmes }}$ Journées de Recherche sur les Palmipèdes à Foie Gras. Arcachon 7/8 Octobre, pp. 69-72

Migaud H, Fontaine P, Sulistyo I, Kestemont P and Gardeur JN 2002. Induction of out-of-season spawning in Eurasian perch Perca fluviatilis: effects of rates of cooling and cooling durations on female gametogenesis and spawning. Aquaculture 205, 253-267. 
Mugnier C, Guennoc M, Lebègue E, Fostier A and Breton B 2000. Induction and synchronisation of spawning in cultivated turbot (Scophthalmus maximus L.) broodstock by implantation of a sustained-release $\mathrm{GnRH}$-a pellet. Aquaculture 181, 241-255.

Blackault J, Brillard JP and Bakst M 2006a. Spermatogenesis in the turkey (Meleagris gallopavo): quantitative approach in immature and adult males subjected to various photoperiods. Theriogenology $65,845-859$.

Blackault J, Brillard JP and Bakst M 2006b. Effect of various photoperiods on testicular weight, weekly sperm output and plasma levels of LH and testosterone over the reproductive season in male turkeys. Theriogenology 66, 851-859.

Notter DR and Cockett NE 2005b. Opportunities for detection and use of QTL influencing seasonal reproduction in sheep: a review. Genetics Selection Evolution 37, (suppl. 1) S39-S53.

Notter DR, Cockett NE and Hadfield T 2003. Evaluation of melatonin receptor $1 \mathrm{a}$ as a candidate gene influencing reproduction in an autumn-lambing sheep flock. Journal of Animal Science 81, 912-917.

Ortavant R, Pelletier J, Ravault JP, Thimonier J and Volland P 1985. Photoperiod: main proximal and distal factor of the circannual cycle of reproduction in farm mammals. Oxford Reviews of Reproductive Biology 7, 305-345

Palmer E and Driancourt MA 1983. Some interactions of season of foaling, photoperiod and ovarian activity in the equine. Livestock Production Science 10, 197-210.

Park YJ, Park JG, Kim SJ, Lee YD, Rahman MS and Takemura A 2006. Melatonin receptor of a reef fish with lunar-related rhythmicity: cloning and daily variations. Journal of Pineal Research 41, 166-174.

Pelletier J, Bodin L, Hanocq E, Malpaux B, Teyssier J, Thimonier J and Chemineau P 2000. Association between expression of reproductive seasonality and alleles of the gene for Mel1a receptor in the ewe. Biology of Reproduction 62, 1096-1101.

Peters RR, Chapin LT, Leining KB and Tucker HA 1978. Supplemental lighting stimulates growth and lactation in catlle. Science 199, 911-912.

Peters RR, Chapin LT, Emery RS and Tucker HA 1981. Milk yield, feed intake, prolactin, growth hormone, and glucocorticoid response of cow to supplemented light. Journal of Dairy Science 64, 1671-1678.

Quirke JF, Hanrahan JP, Loughnane W and Triggs R 1986. Components of the breeding and non-breeding seasons in sheep: breed effects and repeatability. Irish Journal of Agricultural Research 25, 167-172.

Ricordeau G 1982. Selection for reduced seasonality and post-partum anoestrus. Proceedings of the second world congress on genetics applied to livestock production, Madrid, Spain 5, 338-347.

Rius AG and Dahl GE 2006. Exposure to long-day photoperiod prepubertally may increase milk yield in first-lactation cows. Journal of Dairy Science 89, 2080-2083.

Rowan W 1925. Relation of light to bird migration and developmental changes. Nature 115, 494-495.

Saboureau M, Vignault M-P and Ducamp J-J 1991. L'hibernation chez le Hérisson (Erinaceus europeaus L.) dans son environnement naturel: étude par biotélémétrie des variations de la température corporelle. Comptes Rendu de I'Académie des Sciences Paris 313, 93-100.
Saillant E, Chatain B, Fostier A and Fauvel C 2001. Parental influence on early development in the european sea bass (Dicentrarchus labrax). Journal of Fish Biology 58, 1585-1600.

Santiago-Moreno J, Lopez-Sebastian A, Gonzalez-Bulnes A, Gomez-Brunet A and Chemineau P 2000. Seasonal changes in ovulatory activity, plasma prolactin, and melatonin concentrations, in Mouflon (Ovis gmelini musimon) and Manchega (Ovis aries) ewes. Reproduction Nutrition Development 40, 421-430.

Santiago-Moreno J, Lopez-Sebastian A, Gonzalez-Bulnes A, Gomez-Brunet A and Tortonese D 2001. The timing of the onset of puberty, extension of the breeding season, and length of postpartum anestrus in the female mouflon (Ovis gmelini musimon). Journal of Zoo and Wildlife Medicine 32, 230-235.

Sauveur B 1988. Reproduction des volailles et production d'œufs. INRA Editions, Paris.

Sauveur B 1996. Photopériodisme et reproduction des oiseaux domestiques femelles. Productions Animales 9, 25-34.

Shi Q 2005. Melatonin is involved in sex change of the ricefield eel, Monopterus albus Zuiew. Reviews in Fish Biology and Fisheries 15, 23-36.

Shimizu A 2003. Effect of photoperiod and temperature on gonadal activity and plasma steroid levels in a reared strain of the mummichog (Fundulus heteroclitus) during different phases of its annual reproductive cycle. General and comparative endocrinology 131, 310-324

Smith JF, Johnson DL and Reid TC 1992. Genetic parameters and performance of flocks selected for advanced lambing date. Proceedings of the New Zealand Society of Animal Production 52, 50 (abstr.)

Stacey N 2003. Hormones, pheromones and reproductive behavior. Fish Physiology and Biochemistry 28, 229-235.

Stanisiewski EP, Mellenberge RW, Anderson CR and Tucker HA 1985. Effect of photoperiod on milk yield and milk fat in commercial dairy herds. Journal of Dairy Science 68, 1134-1140.

Su G-S, Liljedahl L-E, Graham AE and Gall GAE 1997. Genetic and environmental variation of female reproductive traits in rainbow trout (Oncorhynchus mykiss). Aquaculture 154, 115-124.

Thimonier J and Mauléon P 1969. Variations saisonnières du comportement d'oestrus et des activités ovariennes et hypophysaires chez les ovins. Annales de Biologie Animale, Biochimie, Biophysique 9, 233-250.

Thimonier J and Sempere A 1989. La reproduction chez les cervidés. Productions Animales 2, 5-21.

Vila-Gispert A, Moreno-Amich R and Garcia-Berthou E 2002. Gradients of lifehistory variation: an intercontinental comparison of fishes. Reviews in Fish Biology and Fisheries 12, 417-427.

Webb JH and McLay HA 1996. Variation in the time of spawning of Atlantic salmon (Salmo salar) and its relationship in the Aberdeenshire Dee, Scotland. Canadian Journal of Fish Research and Aquatical Fish Science 53, 2739-2744.

Yenikoye A 1984. Annual variations in estrual behavior, rate and possibilities for ovulation in Peulh ewes from Niger. Reproduction Nutrition Development 24, 11-19.

Zohar Y, Billard R and Weil C 1984. La reproduction de la daurade (Sparus aurata) et du bar (Dicentrarchus labrax): connaissance du cycle sexuel et contrôle de la gamétogenèse et de la ponte. In L'aquaculture du bar et des sparidés (ed. G Barnabé and R Billard), pp. 3-24, INRA Editions, Paris. 